\title{
The Auburn University Shade Tree Evaluation: Its Roots and Fruit
}

J. David Williams, ${ }^{1}$ Charles H. Gilliam, ${ }^{2}$ Gary J. Keever, ${ }^{2}$ and John T. Owen ${ }^{3}$

Additional indeX words. variety trial, landscape

Summary. The Auburn University Shade Tree Evaluation is an ongoing trial of a moderately diverse range of species, and varieties of larger-growing trees. The study was initiated in 1980 with the planting of 250 selections in three replications of three trees each, located at the Alabama Agricultural Experiment Station, Piedmont Substation in east-central Alabama. Among the fruit of the investigation have been an evaluation of 10 red maple (Acer rubrum) selections with respect to growth and fall color characteristics; a comparison of growth rate and aesthetic characteristics of 14 oak (Quercus) selections; a comparison of the growth and fireblight (Erwinia amylovora) susceptibility of 10 callery pear (Pyrus calleryana) selections; and a 12-year evaluation of the overall best performing trees. The Shade Tree Evaluation has served as a precedent for six additional landscape tree evaluations in Alabama. It has provided a living laboratory for a wide range of educational audiences including landscape and nursery professionals, county extension agents, urban foresters, Master Gardeners, garden club members, and horticulture students. Knowledge gained from the Shade Tree Evaluation has been shared through presentations at meetings and conferences.

The Auburn University Shade Tree Evaluation is a replicated, ongoing evaluation of a moderately diverse range of species and varieties of larger growing trees that, at the time the study was implemented, ranged from commonly used to rarely used landscape trees in the South.

The study is located at the Alabama Agricultural Experiment Station (AAES), Piedmont Substation adjacent to Camp Hill, about 25 miles (40 $\mathrm{km}$ ) northwest of Auburn. The substation is situated about 90 miles (145 $\mathrm{km}$ ) southeast of Birmingham, and about 60 miles $(97 \mathrm{~km})$ northeast of Montgomery, two of the largest metropolitan areas in Alabama. The evaluation site occupies about 20 acres ( $8 \mathrm{ha}$ ) and is characterized by gently rolling terrain typical of the piedmont plateau region of the state. The soil type is a Cecil gravelly sandy loam. A total of $\mathbf{5 7 2}$ trees, consisting of 95 different selections are currently maintained in the evaluation (Table 1).

\section{Roots}

The Auburn University Shade Tree Evaluation was born out of concern that many of the tree selection recommendations made for consumers, landscape professionals and municipalities were not based on scientific evaluation, but rather on testimony, nursery advertisements, or popular literature.

\footnotetext{
The cost of publishing this paper was defrayed in part by the payment of page charges. Under postal regulations, this paper therefore must be hereby marked advertisement solely to indicate this fact.

${ }^{1}$ Associate professor, Department of Horticulture, 101 Funchess Hall, Auburn University, AL 36849.

${ }^{2}$ Professor, Department of Horticulture, 101 Funchess Hall, Auburn University, AL 36849.

${ }^{3}$ Superintendent, Piedmont Substation, Camp Hill, AL 36850.
} 
Limited tree evaluations had been performed by arboreta, cities, and universities, especially related to the regional adaptability of these trees. Trees were often selected for use in landscapes before adequate information was available. For example, many trees were selected for use because of their excellent fall foliar color in other regions of the country. However, many of these tree selections did not provide good fall color under climatic conditions common in the southeastern United States. High temperatures, high humidity and different daylengths from where they were selected may suppress fall color development in trees that have outstanding fall color elsewhere. Inadequate information has led to the use of trees that are poorly suited to landscapes in the southern U.S., resulting in poor performance, high maintenance, and high removal costs. A lack of regional evaluation at the time led to research being initiated to provide information about growth, aesthetic characteristics, and adaptability of selected shade and ornamental trees for the southeastern United States.

The objective of the Auburn University Shade Tree Evaluation is to provide information about characteristics and adaptability of selected shade trees for the southeastern United States. Because of its size and scope, this project remains unique in the region.

\section{Project initiation}

Initial plantings were made in Dec. 1980 and continued through winter of 1981. Bareroot whips, 3 to $4 \mathrm{ft}$ ( 1.0 to $1.2 \mathrm{~m}$ ) tall, were planted in a Cecil gravelly sandy loam soil. Subsequent tree plantings were made from 1982 until 1985 resulting in a total of 250 selections. Trees were planted $25 \mathrm{ft}$ within rows and $30 \mathrm{ft}$ between rows $(7.6$ $\times 9.1 \mathrm{~m})$. Three trees each were planted in three replications, for a total of nine trees of each selection in a randomized complete block design. Supplemental irrigation was not applied. A complete fertilizer $(13 \mathrm{~N}-5 \mathrm{P}-10.5 \mathrm{~K})$ was applied in early spring at $\mathrm{l} \mathrm{lb} \mathrm{N} / \mathrm{l}$ inch caliper $\left(178 \mathrm{~g} \cdot \mathrm{cm}^{-1}\right.$ caliper $)$.

Evaluation criteria were annual growth rate, natural attrition, and aesthetic characteristics (flowering and fall color). Growth rate was determined annually by recording tree height, canopy spread, and caliper [measured 12 inches $(30 \mathrm{~cm})$ above the soil line].

\section{Continued management}

Initially, soil tests were made on an annual basis and in 1986, 2 tons/ acre $\left(4400 \mathrm{~kg} \cdot \mathrm{ha}^{-1}\right)$ of agricultural lime was applied; none has been applied since then. The current nutritional program consists of one maintenance fertilizer application of $\mathrm{N}$ at $\mathrm{l} \mathrm{lb} /$ inch caliper, made annually in late winter. Until 1987, weed control consisted of two applications per year of glyphosate or paraquat for post-emergence weed control, and a spring application of oryzalin at (a.i.) $4 \mathrm{lb} /$ acre $\left(4.5 \mathrm{~kg} \cdot \mathrm{ha}^{-}\right.$ ${ }^{1)}$ for preemergence weed control. Herbicides were applied with a directed spray at the base of each tree. Since that time, weed control has involved only the postemergence controls. No preventive insecticide or fungicide applications have been made. Limited selective pruning occurred predominately during the dormant season, except for removal of suckers at the base of the trees (discontinued in 1994).

Attrition of poorly adapted trees has resulted in the current number of 95 tree selections remaining in the trial. Many of the trees have encroached on one another so plots are being thinned by removal of the center tree in each replication.

\section{Fruit}

Audiences served by this project have been diverse and far reaching, including consumers, landscape architects and designers, arborists, landscape contractors, utility company personnel, urban foresters, commercial plant producers, county extension agents and other educators, and master gardeners. The benefits of the study are presented within the framework of the traditional landgrant mission of Auburn University-research, extension, and instruction.

\section{Research products}

We have identified 24 selections that were subject to a high rate of attrition; that is, the majority of the trees of that selection have not survived. Many of these could be considered to be poorly adapted to the region due to their being introduced from other geographic areas (Williams et al., 1993). Callery pear and nine varieties were compared with respect to growth rate, flowering characteristics, and susceptibility to fireblight. Fireblight was found to be a severe problem in 'Aristocrat' and 'Autumn Blaze' (Fare et al., 1991). Fourteen oak selections were evaluated for landscape potential based on growth rate. Sawtooth oak (Quercus acutissima) was noted as the fastest growing selection (Fare et al., 1992). In a comparison of 10 red maple selections, 'Autumn Flame', 'Tilford', 'Gerling', and 'Bowhall' were identified as having the most consistent fall color characteristics (Fare et al., 1990). Top-performing trees were characterized based on vigor, appearance, and landscape use potential in the region (Williams et al., 1995).

Results of the research to date have been shared at International Society of Arboriculture Conferences in Chicago in 1991, Vancouver, B.C., in 1988, and Halifax, N.S., in 1994. Presentations were made at the Southern Nurserymen's Association research conference in Atlanta in 1987 and 1988.

Besides the direct benefits of the Shade Tree Project, this study has set a precedent for establishing five additional long term tree evaluations: An evaluation of 16 red maple selections initiated in 1990 and an evaluation of 17 sugar maple (Acer saccharum) selections initiated in 1992, both at the Piedmont Substation; an evaluation of 60 flowering crabapple (Malus) varieties in 1992 at the AAES Brewton Experimental Field; a trial of $38 \mathrm{dog}$ wood (Cornus) varieties and species and a study of 45 crapemyrtle (Lagerstroemia) selections, both initiated in 1993 at Auburn University; and a study of 60 crapemyrtle selections initiated in 1998 at the AAES Gulf Coast Substation in Fairhope. All of these studies are ongoing.

\section{Future research}

Data have been collected for a comparison of incidence and extent of surface rooting and suckering among various selections. An evaluation of southern magnolia (Magnolia grandiflora) growth rate and foliar characteristics has been submitted for publication. A comparison of the various ash (Fraxinus) selections and an update of a report originally describing performance of oak selections in the study are some of the immediate issues under consideration for further investigation. 


\section{Extension products}

Knowledge gained through this project has been shared with a diverse range of audiences in many settings and through various media.

Field days. Two AAES Piedmont Substation Shade Tree Field Days were held in 1993. In August, the program emphasized the comparative growth rates and general characteristics of the trees. A Fall Color Field Day in October allowed participants to observe the differences in foliar color intensity and relative timing of fall coloration among the selections in the trial.

INDUSTRY CONTACT. Commercial plant producers and retailers have received benefits of the study through presentations at the Alabama Nurserymen's Association Conference and Tradeshow in 1988 through 1991. Nursery professionals have toured individually and in groups to make personal observations about selections in the study. Information gained in the evaluation was featured in the 1986 manager's training school for the Alabama Farmer's Cooperatives. Publications resulting from the study have been cited in American Nurseryman magazine (American Nurseryman, 1994).

EXtension AGENT training AND Master Gardeners. In May 1994, 32 Alabama Cooperative Extension agents received instruction about selected trees in a $\mathrm{l}-\mathrm{d}$, in-service workshop on the evaluation site. These agents have disseminated the knowledge gained from this workshop to landscape professionals, growers and the gardening public.

The Master Gardener Program has become an effective tool for multiplying educational outreach efforts among consumers. Volunteers in this successful program have gained insights from this trial through numerous tours, presentations and Master Gardener classes since 1993. Results of the evaluation were presented at a statewide Master Gardener Conference in 1994 and to a regional audience at the Southeast Master Gardener Continued Training Conference in 1996, as well.

Allied agencies and other STAKEHOLDERS. Tree selection information based on the study was presented at the statewide Alabama Forestry Commission Personnel Training

Table 1. Tree selections currently maintained in the Auburn University Shade Tree Evaluation at the Alabama Agricultural Experiment Station, Piedmont Substation, in east-central Alabama.

\begin{tabular}{|c|c|c|}
\hline $\begin{array}{l}\text { Common } \\
\text { name }\end{array}$ & $\begin{array}{l}\text { Scientific } \\
\text { name }\end{array}$ & $\begin{array}{l}\text { Varietal } \\
\text { name }\end{array}$ \\
\hline Florida maple & Acer barbatum & --- \\
\hline Trident maple & Acer buergeranum & --- \\
\hline Paperbark maple & Acer griseum & --- \\
\hline Chalk maple & Acer leucoderme & --- \\
\hline Boxelder & Acer negundo & --- \\
\hline \multirow[t]{9}{*}{ Red maple } & Acer rubrum & --- \\
\hline & Acer rubrum & Armstrong \\
\hline & Acer rubrum & Autumn Flame \\
\hline & Acer rubrum & Bowhall \\
\hline & Acer rubrum & Red Sunset ${ }^{\mathrm{R}}$ \\
\hline & Acer rubrum & Gerling \\
\hline & Acer rubrum & Scarlet Sentinel ${ }^{\mathrm{TM}}$ \\
\hline & Acer rubrum & Schlesingeri \\
\hline & Acer rubrum & Tilford \\
\hline Silver maple & Acer saccharinum & --- \\
\hline Shantung maple & Acer truncatum & --- \\
\hline \multirow[t]{2}{*}{ River birch } & Betula nigra & --- \\
\hline & Betula nigra & Heritage \\
\hline Paper birch & Betula papyrifera & --- \\
\hline Birch & Betula sp. & --- \\
\hline Japanese hornbeam & Carpinus japonica & --- \\
\hline Water hickory & Carya aquatica & --- \\
\hline Yellowwood & Cladrastis lutea & --- \\
\hline Hardy rubber tree & Eucommia ulmoides & --- \\
\hline Chinese parasol tree & Firmiana simplex & --- \\
\hline \multirow[t]{5}{*}{ White ash } & Fraximus americana & --- \\
\hline & Fraxinus americana & Autumn Applause \\
\hline & Fraximus americana & Autumn Purple ${ }^{\mathrm{R}}$ \\
\hline & Fraxinus americana & Champaign County \\
\hline & Fraxinus americana & Skyline $^{\mathrm{R}}$ \\
\hline European ash & Fraxinus excelsior & Kimberly \\
\hline Green ash & Fraxinus lanceolata & --- \\
\hline Japanese ash & Fraxinus longicuspis & --- \\
\hline Claret ash & Fraxinus oxycarpa & Raywood \\
\hline \multirow[t]{5}{*}{ Green ash } & Fraxinus pennsylvanica & Bergeson \\
\hline & Fraxinus pennsylvanica & Emerald \\
\hline & Fraxinus pennsylvanica & Marshall Seedless \\
\hline & Fraxinus pennsylvanica & Newport $^{\mathrm{TM}}$ \\
\hline & Fraxinus pennsylvanica & Summit \\
\hline Blue ash & Fraxinus quadrangulata & --- \\
\hline Maidenhair tree & Ginkgo biloba & --- \\
\hline Kentucky coffee tree & Gymnocladus dioicus & --- \\
\hline Chinese flame tree & Koelveuteria bipinnata & --- \\
\hline Panicled goldenraintree & Koelreuteria paniculata & --- \\
\hline Tulip poplar & Liriodendron tulipifera & --- \\
\hline Henry tanbark oak & Lithocarpus henryi & --- \\
\hline Southern magnolia & Magnolia grandiflora & --- \\
\hline
\end{tabular}

Workshop in 1994. Alabama Forestry Commission personnel have received on-site instruction. Some of the outstanding selections were featured at the Alabama Urban Forestry Association Convention in 1996. Information gained though the study and delivered to these professionals has been carried to community tree programs.
Community tree program recommendations for landscape and street tree plantings have cited the study as their authority.

The Shade Tree Evaluation results have been shared with numerous garden clubs and through public meetings throughout Alabama from 1993 through 1999. One significant visitor 
Table 1. Continued.

\begin{tabular}{|c|c|c|}
\hline $\begin{array}{l}\text { Common } \\
\text { name }\end{array}$ & $\begin{array}{l}\text { Scientific } \\
\text { name }\end{array}$ & $\begin{array}{l}\text { Varietal } \\
\text { name }\end{array}$ \\
\hline & $\begin{array}{l}\text { Magnolia grandiflora } \\
\text { Magnolia grandiflora } \\
\text { Magnolia grandiflora } \\
\text { Magnolia grandiflora } \\
\text { Magnolia grandiflora } \\
\text { Magnolia grandiflora } \\
\text { Magnolia grandiflora } \\
\text { Magnolia grandiflora } \\
\text { Magnolia grandiflora } \\
\text { Magnolia grandiflora } \\
\text { Magnolia grandiflora }\end{array}$ & $\begin{array}{l}\text { Aldridge } \\
\text { Bracken Brown Beauty } \\
\text { Claudia Wannamaker } \\
\text { Glen St. Mary } \\
\text { Hasse } \\
\text { Little Gem } \\
\text { Majestic Beauty } \\
\text { Margaret Davis } \\
\text { Shady Grove \# } 4 \\
\text { Shady Grove \# } 5 \\
\text { Shady Grove \# } 6\end{array}$ \\
\hline Dawn redwood & Metasequoia glyptostroboides & -- \\
\hline Ogeechee tupelo & Nyssa ogeche & --- \\
\hline Black gum & Nyssa sylvatica & --- \\
\hline Amur cork tree & Phellodendron amurense & --- \\
\hline Chinese pistache & Pistacia chinensis & --- \\
\hline \multirow[t]{8}{*}{ Callery pear } & Pyrus calleryana & Callery pear \\
\hline & Pyrus calleryana & Aristocrat \\
\hline & Pyrus calleryana & Bradford \\
\hline & Pyrus calleryana & Capital \\
\hline & Pyrus calleryana & Cleveland Select \\
\hline & Pyrus calleryana & Fauriei \\
\hline & Pyrus calleryana & Redspire \\
\hline & Pyrus calleryana & Whitehouse \\
\hline Sawtooth oak & Quercus acutissima & --- \\
\hline White oak & Quercus alba & --- \\
\hline Scarlet oak & Quercus coccinea & --- \\
\hline Overcup oak & Quercus lyrata & --- \\
\hline Bur oak & Quercus macrocarpa & --- \\
\hline Water oak & Quercus nigra & --- \\
\hline Pin oak & Quercus palustris & --- \\
\hline Pin oak & Quercus palustris & Crownright \\
\hline Willow oak & Quercus phellos & --- \\
\hline Chestnut oak & Quercus prinus & --- \\
\hline English oak & Quercus robur & Fastigiate \\
\hline Northern red oak & Quercus rubra & --- \\
\hline Shumard oak & Quercus shumardii & --- \\
\hline Live oak & Quercus virginiana & --- \\
\hline Japanese pagoda tree & Sophora japonica & --- \\
\hline Common baldcypress & Taxodium distichum & --- \\
\hline Sweet nutans baldcypress & Taxodium distichum nutans & --- \\
\hline Montezuma cypress & Taxodium mucronatum & --- \\
\hline Littleleaf linden & Tilia cordata & Glenleven \\
\hline \multirow[t]{2}{*}{ Chinese elm } & Ulmus parvifolia & Caitlin \\
\hline & Ulmus parvifolia & Frosty \\
\hline \multirow[t]{3}{*}{ Japanese zelkova } & Zelkova serrata & --- \\
\hline & Zelkova serrata & Green Vase \\
\hline & Zelkova serrata & Village Green \\
\hline
\end{tabular}

to the trial was the president of $\mathrm{Au}$ burn University and his wife who stopped to tour the site on an unofficial basis for their own enlightenment.

Instructional products. Classes have visited the site, including a tour by students from the horticulture program at Jefferson State Community College in Birmingham in been involved in tree identification and project site map updating.

\section{Conclusion}

In a recent evaluation of all Alabama Agricultural Experiment Station facilities, the Auburn University Shade Tree Evaluation was cited as the most important work at the AAES Piedmont Substation. The Auburn University Shade Tree Evaluation has provided significant benefits to a wide audience statewide and regionally. There is great potential for gaining knowledge about mature tree performance in the southeastern U.S.

\section{Literature cited}

American Nurseryman, 1994. Alabama researchers compile shade tree manual. Amer. Nurseryman 179(10):87-88 .

Fare, D.C., C.H. Gilliam, H.G. Ponder, G.K. Keever, and J.D. Williams. 1992. Oaks evaluated for potential use in the urban landscape. J. Arboricult. 18:333.

Fare, D.C., C.H. Gilliam, and H.G. Ponder. 1991. Fireblight susceptibility, growth and other characteristics in ornamental pears in Alabama. J. Arboricult. 17:257260.

Fare, D.C., C.H. Gilliam, and H.G. Ponder. 1990. Acer rubrum cultivars for the South. J. Arboricult. 16:25-29.

Williams, J.D., D.C. Fare, C.H. Gilliam, G.J. Keever, H.G. Ponder, J.T. Owen, and G. Creech. 1995. Superior shade tree selections for the southeastern United States. J. Arboricult. 21:118-121.

Williams, J.D., D.C. Fare, C.H. Gilliam, G.J. Keever, H.G. Ponder, and J.T. Owen. 1993. Trees for the southeastern United States: An Auburn University evaluation. Brown Printing Company, Montgomery, Ala. p. 132.
1998. In the instructional program at Auburn University knowledge gained from the study has been highly utilized in Arboriculture (HORT 3220), Small Trees, Shrubs and Vines (HORT 3210), Landscape Gardening (HORT 2210), and Introduction to Horticulture (HORT 1010). In Directed Studies(HORT 4260) several students have 